University of Nebraska - Lincoln

DigitalCommons@University of Nebraska - Lincoln

USDA Wildlife Services - Staff Publications

U.S. Department of Agriculture: Animal and Plant Health Inspection Service

2009

\title{
Declining Mortality in American Crow (Corvus Brachyrhynchos) Following Natural West Nile Virus Infection
}

\author{
Lisa M. Reed \\ Center for Vector Biology, Rutgers University, 180 Jones Avenue, New Brunswick, NJ 08901, \\ Ireed@rci.rutgers.edu \\ Michael A. Johansson \\ Division of Vector-borne Infectious Diseases, Centers for Disease Control and Prevention \\ Nicholas Panella \\ Division of Vector-borne Infectious Diseases, Centers for Disease Control and Prevention \\ Robert McLean \\ USDA-APHIS-Wildlife Services \\ Terry Creekmore \\ Wildlife Division, Wyoming Game and Fish
}

See next page for additional authors

Follow this and additional works at: https://digitalcommons.unl.edu/icwdm_usdanwrc

Part of the Environmental Sciences Commons

Reed, Lisa M.; Johansson, Michael A.; Panella, Nicholas; McLean, Robert; Creekmore, Terry; Puelle, Rose; and Komar, Nicholas, "Declining Mortality in American Crow (Corvus Brachyrhynchos) Following Natural West Nile Virus Infection" (2009). USDA Wildlife Services - Staff Publications. 948.

https://digitalcommons.unl.edu/icwdm_usdanwrc/948

This Article is brought to you for free and open access by the U.S. Department of Agriculture: Animal and Plant Health Inspection Service at DigitalCommons@University of Nebraska - Lincoln. It has been accepted for inclusion in USDA Wildlife Services - Staff Publications by an authorized administrator of DigitalCommons@University of Nebraska - Lincoln. 


\section{Authors}

Lisa M. Reed, Michael A. Johansson, Nicholas Panella, Robert McLean, Terry Creekmore, Rose Puelle, and Nicholas Komar 


\title{
Research Note-
}

\section{Declining Mortality in American Crow (Corvus brachyrhynchos) Following Natural West Nile Virus Infection}

\author{
Lisa M. Reed, ${ }^{\mathrm{AF}}$ Michael A. Johansson, ${ }^{\mathrm{B}}$ Nicholas Panella, ${ }^{\mathrm{B}}$ Robert McLean, ${ }^{\mathrm{C}}$ Terry Creekmore, ${ }^{\mathrm{D}}$ Rose Puelle, ${ }^{\mathrm{E}}$ \\ and Nicholas $\operatorname{Komar}^{\mathrm{B}}$
}

\begin{abstract}
${ }^{A}$ Center for Vector Biology, Rutgers University, 180 Jones Avenue, New Brunswick, NJ 08901
${ }^{B}$ Division of Vector-borne Infectious Diseases, Centers for Disease Control and Prevention, 3150 Rampart Road, Fort Collins, CO 80521

${ }^{\mathrm{C}}$ Wildlife Disease Research Program, National Wildlife Research Center, United States Department of Agriculture, 4101 La Porte Avenue, Fort Collins, CO 80521

DWildlife Division, Wyoming Game and Fish, 528 South Adams Street, Laramie, WY 82070

${ }^{E}$ Public Health Preparedness, Public Health, P.O. Box 2900, Hunterdon County, NJ 08822
\end{abstract}

Received 20 October 2008; Accepted and published ahead of print 29 March 2009

\begin{abstract}
SUMMARY. The American crow (Corvus brachyrhynchos) is known to suffer 100\% mortality from infection with the New York 1999 strain of West Nile virus (WNV). Following the initial detection of WNV in North America in 1999, we measured prevalence of WNV-reactive antibodies ("seroprevalence") in free-ranging American and fish crows (Corvus ossifragus) of central New Jersey after each transmission season through 2005. In 2002, seroprevalence in American crow juveniles increased to 14\% from the $5 \%$ of the previous year, potentially indicating increased survival in this species. Using the annual seroprevalence measurements and the number of human West Nile neuroinvasive disease cases as a surrogate for WNV transmission intensity, we developed a model to estimate the annual WNV-associated mortality rates among both of these crow species. Our model supports the hypothesis that mortality is changing over time; the WNV-associated mortality rate declined over time by $1.5 \%$ for American crow and by $1.1 \%$ for fish crow. The probability that the trend in mortality was negative was $90 \%$ for the American crow and $60 \%$ for the fish crow.
\end{abstract}

RESUMEN. Nota de Investigación-Disminución en la mortalidad de cuervos americanos (Corvus brachyrhynchos) después de la infección natural por el virus del oeste del Nilo.

Se conoce que el cuervo americano (Corvus brachyrhynchos) sufre una mortalidad del $100 \%$ por la infección con la cepa New York 1999 del virus del oeste del Nilo. Después de la detección inicial del virus del oeste del Nilo en América del Norte en el año 1999, se determinó la prevalencia de anticuerpos contra dicho virus ("seroprevalencia") en cuervos americanos y en cuervos pescadores (Corvus ossifragus) de vida libre en la parte central de New Jersey después de cada temporada de transmisión durante el año 2005. En el año 2002, la seroprevalencia en cuervos americanos jóvenes se incrementó al 14\% en comparación con el 5\% observado en el año anterior, lo que potencialmente indica un incremento en la supervivencia de estas especies. Utilizando los datos de seroprevalencia y el número de casos en humanos de la forma neuroinvasiva de la enfermedad del oeste el Nilo como un indicador de la intensidad en la transmisión de la enfermedad, se desarrolló un modelo para estimar los porcentajes de mortalidad asociados al virus del oeste del Nilo en ambas especies de cuervos. Este modelo apoya la hipótesis de que la mortalidad está cambiando con el tiempo, el porcentaje de mortalidad asociada a la enfermedad ha disminuido en un $1.5 \%$ para el cuervo americano y en un $1.1 \%$ para el cuervo pescador. La probabilidad de que la tendencia en la mortalidad sea negativa fue del $90 \%$ para el cuervo americano y del $60 \%$ para el cuervo pescador.

Key words: West Nile virus, crows, corvids, seroprevalence, infection, mortality

Abbreviations: PRNT = plaque reduction neutralization test; WNND = West Nile neuroinvasive disease; WNV $=$ West Nile virus

West Nile virus (WNV), a pathogenic arbovirus with avian primary hosts and culicid vectors, is associated with significant corvid mortality in North America (25). Numerous corvids are susceptible to WNV, including the American crow (Corvus brachyrhynchos) in particular, but also fish crow (Corvus ossifragus), two species of magpies (Pica spp.), and several species of jays (e.g., Cyanocitta spp.) (10,19,20,32). Prior to the introduction of WNV in the Western Hemisphere in 1999, large numbers of crow deaths due to infectious diseases were unusual. Since 1999, dead crows have tested positive for acute WNV infection at alarming rates $(2,27)$, and clusters of dead crows have spatially predicted human cases of WNV-induced disease (15,30,32).

Corvid mortality quickly became a hallmark of the North American WNV invasion and was promoted as an early warning

${ }^{\mathrm{F} C}$ Corresponding author. E-mail: 1reed@rci.rutgers.edu signal for local WNV activity $(14,16)$. Experimental infections of American crows with the New York 1999 strain revealed that 100\% of infected crows succumbed and that crows became infected from each other in the absence of mosquito vectors $(20,26)$, an observation that has been corroborated in the field (13). The New York 1999 strain was found to contain a bird-virulent mutation that permitted replication at the high body temperatures reached by febrile crows and other birds $(4,5)$. Local WNV transmission to American crows was so intense in the eastern United States (3) that some local populations declined by almost $70 \%(9,35)$.

In spite of the substantial die-offs of crows associated with WNV, avian mortality surveillance seemed to gradually lose sensitivity for early detection of WNV, relative to other surveillance activities $(6,28)$. The sensitivity of avian mortality surveillance for detecting WNV may decrease over time due to diminishing populations of WNV-sensitive bird species, to an accumulation of surviving birds that resist infection 
due to innate and acquired immunity and, in the case of species with high mortality rates, to selection of mortality-resistant genotypes (18). However, these explanations have not been proven in the case of the WNV epizootic in North America. We sought to corroborate the decrease in sensitivity of corvid-based avian mortality surveillance for WNV by evaluating the survival rates among crows naturally infected with WNV in New Jersey in the years following WNV introduction. Accordingly, we determined WNV-reactive antibody prevalence ("seroprevalence") rates among free-ranging American and fish crows following each WNV transmission season from 1999 through 2005 in central New Jersey. We then used West Nile neuroinvasive disease (WNND) incidence in humans as a measure of transmission intensity and, therefore, as an indicator of crow infection rates that would be independent of crow mortality. Given observed seroprevalence rates and this human case-derived infection rate, we could then estimate annual mortality rates to evaluate concurrent changes in mortality (and thus, survival) over time.

\section{MATERIALS AND METHODS}

American and fish crows were trapped at the solid waste facilities at Middlesex County Utilities Authority (Edgeboro), East Brunswick, New Jersey. This 300-ac landfill, located near the Raritan Bay, receives about 2600 solid-trash tons/day and is located about $52 \mathrm{~km} \mathrm{SW}$ from the Borough of Queens, New York, where human WNND cases were first reported in the United States. The trap was located close to compost piles adjacent to the landfill. A previous study demonstrated that crows from at least $4 \mathrm{~km}$ away visited the compost piles (8). Trapping took place from late fall (beginning in late October) through early spring (ending in early April) of each year. Although traps were in place throughout the fall, winter, and spring of each year, the number of times crows were successfully caught varied considerably. This resulted in a wide variation of birds being caught and, subsequently, the latter years are represented by fewer birds and, thus, more uncertainty for the seroprevalence measures.

Crows were caught using a drop-in style trap, commonly called a Scandinavian or Australian crow trap (7). Crows were identified to species and age based on tarsus or culmen length (31), voice, or P9/P5 ratios among the primary feathers of the wing (24) and then banded with a United States Geological Survey band. A 2-ml sample of blood was taken via jugular venipuncture, allowed to coagulate for $30 \mathrm{~min}$, and placed on ice. After sampling, the birds were held for 20 min to ensure that the puncture areas were not bleeding and then released nearby. Samples were centrifuged at $1288 \times g$ at $4 \mathrm{C}$ for $30 \mathrm{~min}$, to separate red blood cells from serum, and stored at -70 C. Prior to 2003 , samples were analyzed by a plaque reduction neutralization test (PRNT) for antibody detection (1). Beginning in 2003, samples were screened for antibodies using a WNVspecific blocking enzyme-linked immunosorbent assay (17). Positive samples were confirmed using PRNT. Samples were collected according to established Biohazard Safety-Animal protocols at Rutgers University.

To test the hypothesis that mortality is changing over time, we adopted a Bayesian approach to analyze the relationship between seroprevalence in juvenile birds, $s$, after transmission season, $t$, as a function of WNV incidence, $i$, and WNV-associated mortality, $m$, as described by Komar et al. (21):

$$
s_{t}=\frac{i_{t}-i_{t} m_{t}}{1-i_{t} m_{t}}
$$

The Bayesian approach allowed us to estimate these parameters while considering the uncertainty in each of them. They were estimated by simulation in WinBUGS (Version 1.4; MRC Biostatistics Unit, Cambridge, U. K. and Imperial College School of Medicine, London, U. K.) (23) (code is available from the authors upon request).

The seroprevalence $s_{t}$ is estimated from a binomial distribution,

$$
y_{t} \sim \operatorname{Binomial}\left(s_{t}, n_{t}\right),
$$

where $y_{t}$ is the number of seropositive juvenile birds out of those tested, $n_{t}$. Juvenile birds are used exclusively in the model for every transmission season after 1999, because they are assumed to be universally susceptible to infection at the beginning of the transmission season. All birds were used for 1999 because the virus was not previously present in the United States and, therefore, no adult birds would have had pre-existing immunity.

Initial mortality, $m_{0}$, was estimated for each species based on data from laboratory-infected crows $(5,20,26,33)$,

$$
d \sim \operatorname{Binomial}\left(m_{0}, n\right)
$$

where $d$ is the number of birds that died out of the number infected, $n$. Because our aim was to detect a trend in mortality over time, we modeled mortality as a linear function of time,

$$
m_{t}=m_{0}+\Delta_{m}(t-1)
$$

where $\Delta_{m}$ is the yearly change in mortality.

We used the reported number of WNND cases in humans, $c$, as an indicator of corvid infection rate, $i$. The incidence of human neuroinvasive disease is modeled as a Poisson distribution,

$$
c_{t} \sim \operatorname{Poisson}\left(\lambda_{t}\right)
$$

and avian incidence is assumed to be a function of its mean, $\lambda$,

$$
i_{t}=\alpha \lambda_{t}
$$

where $\alpha$ is a non-zero, positive real number. New Jersey human WNND cases were obtained from Arbonet (Centers for Disease Control and Prevention, unpublished data).

\section{RESULTS AND DISCUSSION}

WNV-specific antibodies were detected annually (1999-2005) in American and fish crows in central New Jersey following the introduction of WNV into the United States (Table 1). Seroprevalence was generally higher for fish crow versus American crow, a pattern also observed in the southern United States (34) and likely explained by a higher WNV-associated mortality rate in American crows. Experimental infection of mature crows with the New York 1999 strain of WNV resulted in approximately 55\% mortality for fish crow and complete mortality for American crow $(5,20,26,33)$. The initial low seroprevalence $(<4 \%)$ in 1999 and 2000 may have resulted from low population exposure to virus, high mortality rates, or both. Indeed, large numbers of crow carcasses of both species were observed in New Jersey during this period, and many of them tested positive for WNV infection (29). Seroprevalence was higher for juveniles of both crow species in 2002, suggesting greater transmission intensity and an increase in survival rate for the American crow. A slight reduction in the virulence of the virus, or an evolutionary selection for genetically adapted crows, could result in increasing antibody seroprevalence rates over time, as more individuals survive infection.

Because the WNV-induced mortality rate of crows in nature is unknown and possibly changing, we used a simple mathematical model that links three variables: seroprevalence, infection rate, and mortality. Mortality is calculated as a function of seroprevalence and infection rate. Because only seroprevalence was directly measured, we used a surrogate for infection rate: the number of human WNND cases. WNND incidence provides a good measure of the intensity of WNV transmission for this region across all years of this study because WNND is a severe disease which is unlikely to be misdiagnosed. To include fluctuating yearly WNV activity in the model, we assumed that WNV incidence in crows is correlated with human WNND incidence and estimated a distribution for the correlation.

Under the assumption that incidence in the crow population correlates linearly with WNND in the human population, we found that mortality decreased slightly, over time, for the American crow (Fig. 1). The probability that the trend in mortality was negative was $90 \%$ for the American crow and $60 \%$ for the fish crow. This 
Table 1. West Nile virus antibody prevalence rates (\%) in American and fish crows, by age, in New Jersey 1999-2005. Sample size ( $n$ ) and confidence intervals $(95 \% \mathrm{CI})$ are given below each seroprevalence.

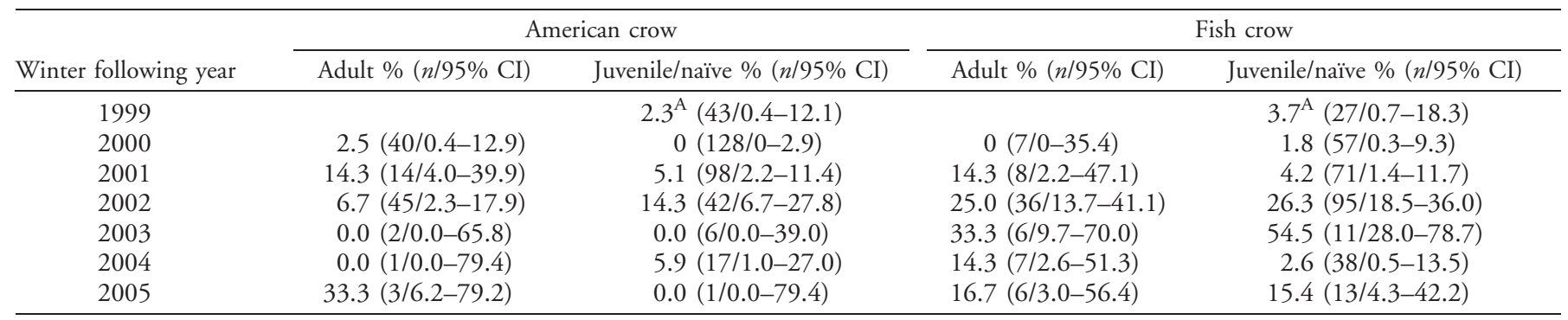

${ }^{\mathrm{A}}$ Denotes the naïve population of 1999 , the year of WNV introduction, and includes both juvenile and adult crows.

increased probability of a mortality reduction is illustrated in Figure 2. The annual median decrease in mortality was approximately $1.5 \%$ per year $(95 \%$ credible interval, $[-0.6 \%, 7.6 \%])$ and $1.1 \%$ per year $[-5.4 \%, 9.7 \%]$ for American and fish crow, respectively. Decreased mortality could be due to increased resistance in the crow population, or to attenuation of WNV itself. Both hypotheses warrant further investigation. Interestingly, a viral-strain shift was observed in the northeast United States in 2002 (12). Although the effects of this strain shift on crow pathogenesis, immune response, and survival are unknown, this 2002 strain was observed to be slightly attenuated in mice (11).

Our study serves to demonstrate the relationship between seroprevalence and mortality rate. These two values vary independent-

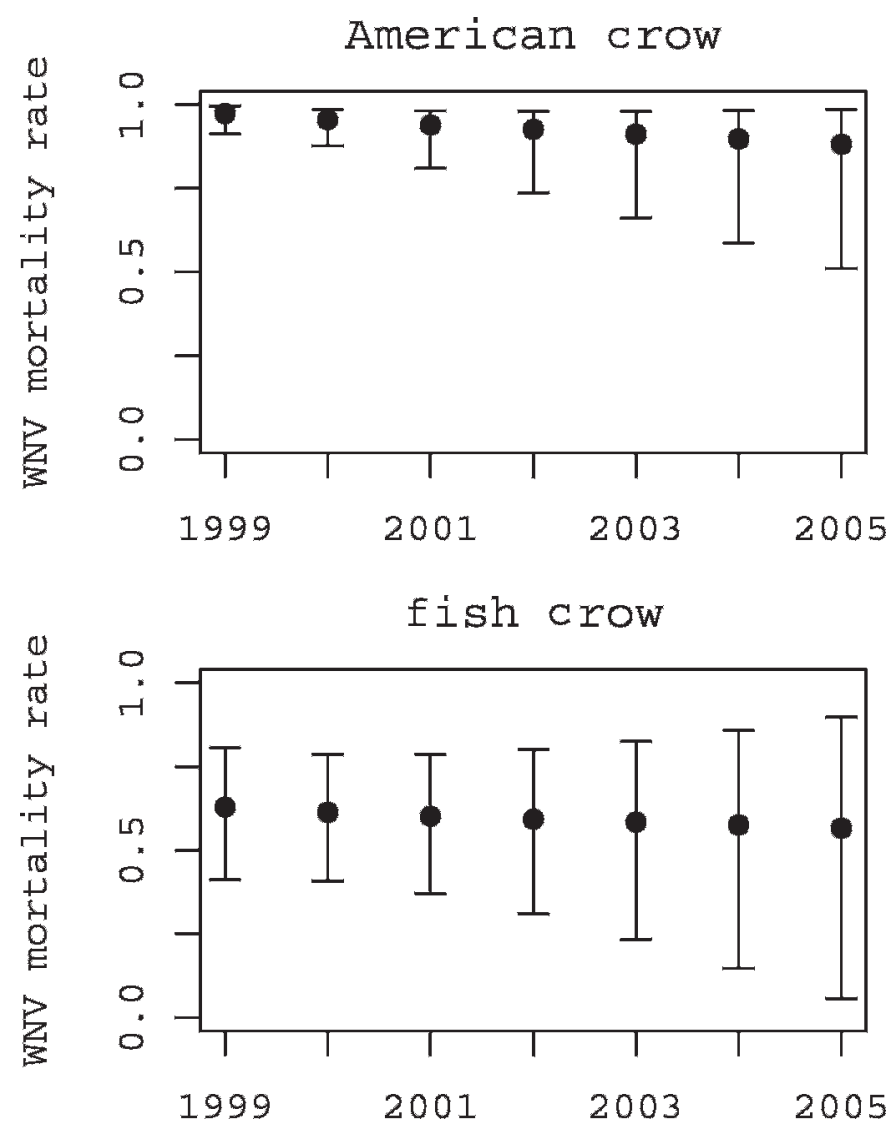

Fig. 1. Estimated naïve American crow (top) and fish crow (bottom) mortality from WNV in New Jersey for the 1999 to 2005 transmission seasons. Naïve populations include both adult and juvenile crows in 1999 (year of WNV introduction) and only juvenile crows for the years 2000-2005. Points and error bars represent the medians and $95 \%$ credible intervals. ly, depending on separate biologic processes. As an example, juvenile fish crow seroprevalence increased after the high transmission seasons of 2002 and 2003 and dropped again in 2004. The pattern of changing seroprevalence in fish crow likely reflects the general changes in WNV activity, rather than a significant change in mortality rate. Other factors that may contribute to variation in avian seroprevalence include attrition of local birds (due to WNV), movement of birds from areas with different WNV activity, or mutations in the WNV genome leading to variations in transmissibility.

The number of carcasses of both species sent in by the public dropped over the study period (29). Sources of this decrease may include decreased public participation, a smaller corvid population and, as our paper reports, an increase in American crow survival. LaDeau et al. (22) found that the introduction of WNV significantly reduced American crow, but not fish crow, abundance through 2005, suggesting that the smaller crow population may be the primary factor leading to fewer crow-carcass submissions. Although declining mortality in crows signals a likely reduction of sensitivity of avian mortality surveillance for WNV, the decline we detected was on the order of $10 \%$ for American

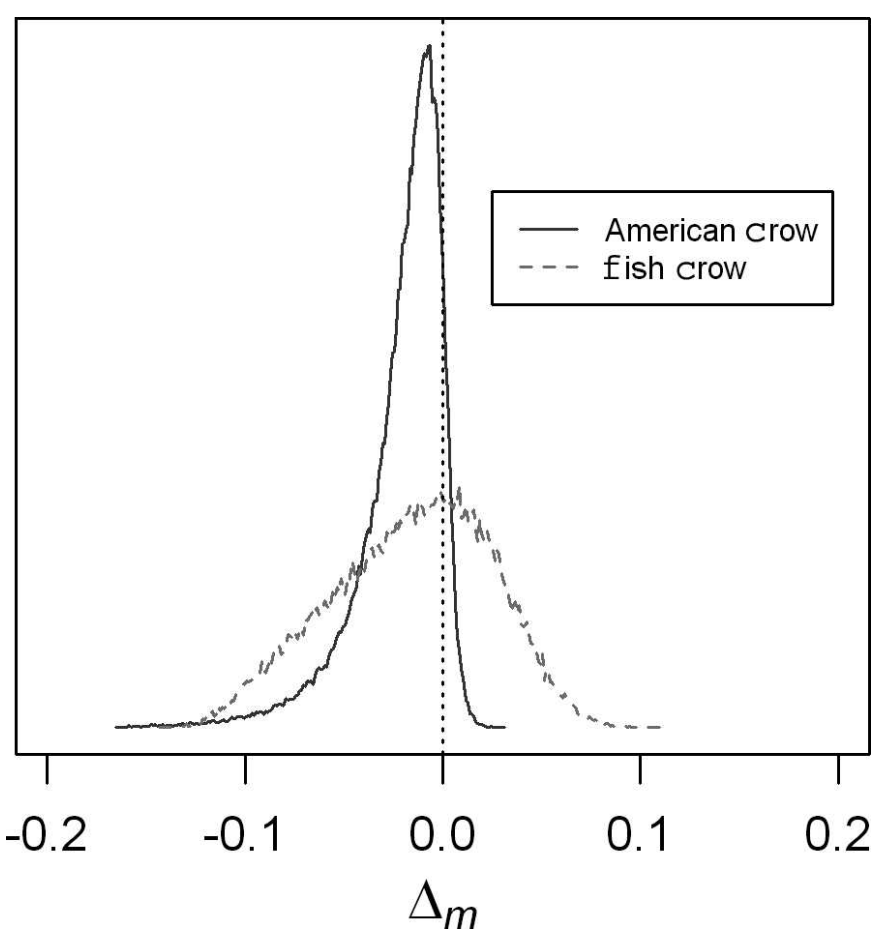

Fig. 2. Sampling distribution of mortality change $(\Delta \mathrm{m})$ for each crow species, 1999 to 2005 . Each distribution is the standardized frequency distribution of 150,000 Bayesian samples (the area under each curve is equal to 1 ). For American crow, $\Delta \mathrm{m}$ was negative in $90 \%$ of the samples and for fish crow in $60 \%$ of the samples. 
crow. Thus, American crow should continue to be an efficient surveillance target in areas where populations remain dense and, thus, carcasses are likely to be detected and reported.

\section{REFERENCES}

1. Beaty, B., C. Calisher, and R. Shope. Arboviruses. In: Diagnostic procedures for viral, rickettsial, and chlamydial infections, 7th ed. Lennette, E. H., D. A. Lennette, and E. T. Lennette, eds. Washington: American Public Health Association. pp. 189-212. 1995.

2. Bernard, K. A., J. G. Maffei, S. A. Jones, E. B. Kauffman, A. P. Dupuis II, K. A. Ngo, D. C. Nicholas, D. M. Young, P-Y. Shi, V. L. Kulasekera, M. Eidson, D. M. White, W. B. Stone, NY State West Nile Virus Surveillance Team, and L. D. Kramer. West Nile virus infection in birds and mosquitoes, New York State, 2000. Emerg. Infect. Dis. 7:679-685. 2001.

3. Bonter, D. N., and W. M. Hochachka. Widespread declines of chickadees and corvids: possible impact of West Nile virus. Amer. Birds 103:22-25. 2003.

4. Brault, A. C., C. Y-H. Huang, S. A. Langevin, R. M. Kinney, R. A. Bowen, W. N. Ramey, N. A. Panella, E. C. Holmes, A. M. Powers, and B. R. Miller. A single positively selected West Nile viral mutation confers increased virogenesis in American crows. Nat. Genet. 39:1162-1166. 2007.

5. Brault, A. C., S. A. Langevin, R. A. Bowen, N. A. Panella, B. J. Biggerstaff, B. R. Miller, and N. Komar. Differential virulence of West Nile strains for American crows. Emerg. Infect. Dis. 10:2161-2168. 2004.

6. Brownstein, J. S., T. R. Holford, and D. Fish. Enhancing West Nile virus surveillance, United States. Emerg. Infect. Dis. 10:1129-1133. 2004.

7. Bub, H. Bird trapping and bird banding: a handbook for trapping methods all over the world. Cornell University Press, Ithaca, New York. 448 pp. 1995.

8. Caccamise, D. F., L. M. Reed, J. Romanowski, and P. C. Stouffer. Roosting behavior and group territoriality in American crows. Auk 114:628-637. 1997.

9. Caffrey, C., S. C. R. Smith, and T. J. Weston. West Nile virus devastates an American crow population. Condor 107:128-132. 2005.

10. Crosbie, S. P., W. D. Koenig, W. K. Reisen, V. L. Kramer, L. Marcus, R. Carney, E. Pandolfino, G. M. Bolen, L. R. Crosbie, D. A. Bell, and H. B. Ernest. Early impact of West Nile virus on the yellow-billed magpie (Pica nuttalli). Auk 123:542-550. 2008.

11. Davis, C. T., D. W. C. Beasley, H. Guzmana, M. Siirin, R. E. Parsons, R. B. Tesh, and A. D. T. Barrett. Emergence of attenuated West Nile virus variants in Texas, 2003. Virology 330:342-350. 2004.

12. Davis, C. T., G. D. Ebel, R. S. Lanciotti, A. C. Brault, H. Guzman, M. Siirin, A. Lambert, R. E. Parsons, D. W. C. Beasley, R. J. Novak, D. Elizondo-Quiroga, E. N. Green, D. S. Young, L. M. Stark, M. A. Drebot, H. Artsob, R. B. Tesh, L. D. Kramer, and A. D. T. Barrett. Phylogenetic analysis of North American West Nile virus isolates, 2001-2004: evidence for the emergence of a dominant genotype. Virology 342:252-265. 2005.

13. Dawson, J. R., W. B. Stone, G. D. Ebel, D. S. Young, D. S. Galinski, J. P. Pensabene, M. A. Franke, M. Eidson, and L. D. Kramer. Crow deaths caused by West Nile virus during winter. Emerg. Infect. Dis. 13:1912-1914. 2007.

14. Eidson, M., L. Kramer, W. Stone, Y. Hagiwara, and the New York State West Nile Virus Avian Surveillance Team. Dead bird surveillance as an early warning system for West Nile virus. Emerg. Infect. Dis. 7:631-635. 2001.

15. Eidson, M., J. Miller, L. Kramer, B. Cherry, Y. Hagiwara, and the West Nile Virus Bird Mortality Analysis Group. Dead crow densities and human cases of West Nile virus, New York State, 2000. Emerg. Infect. Dis. 7:662-664. 2001.

16. Gubler, D. J., G. L. Campbell, R. Nasci, N. Komar, L. Petersen, and J. T. Roehrig. West Nile virus in the United States: guidelines for detection, prevention, and control. Viral Immunol. 3:469-475. 2000.

17. Jozan, M., R. Evans, R. McLean, R. Hall, B. Tengradi, L. Reed, and J. Scott. Detection of West Nile virus infection in birds by blocking ELISA and immunohistochemistry. Vector Borne Zoonotic Dis. 3:99-110. 2003.

18. Komar, N. West Nile virus surveillance using sentinel birds. Ann. N. Y. Acad. Sci. 951:58-73. 2001.

19. Komar, N., R. Lanciotti, R. Bowman, S. Langevin, and M. Bunning. Detection of West Nile virus in oral and cloacal swabs collected from bird carcasses. Emerg. Infect. Dis. 8:741-742. 2002.
20. Komar, N., S. Langevin, S. Hinten, N. Nemeth, E. Edwards, D. Hettler, B. Davis, R. Bowen, and M. Bunning. Experimental infection of North American birds with the New York 1999 strain of West Nile virus. Emerg. Infect. Dis. 9:311-322. 2003.

21. Komar, N., N. A. Panella, S. A. Langevin, A. C. Brault, M. Amador, E. Edwards, and J. C. Owens. Avian hosts for West Nile virus in St. Tammany Parish, Louisiana, 2002. Am. J. Trop. Med. Hyg. 73:1031-1037. 2005.

22. LaDeau, S. L., A. M. Kilpatrick, and P. P. Marra. West Nile virus emergence and large-scale declines of North American bird populations. Nature 447:710-714. 2007.

23. Lunn, D. J., A. Thomas, N. Best, and D. Spiegelhalter. WinBUGSa Bayesian modelling framework: concepts, structure, and extensibility. Statist. Comput. 10:325-337. 2000.

24. McGowan, K. Fish crow (Corvus ossifragus). In: The birds of North America, no. 589. Poole, A., and F. Gill, eds. The Birds of North America, Inc., Philadelphia, PA. Available from: http://bna.birds.cornell.edu/bna/. 2001.

25. McLean, R. G. West Nile virus in North American birds. Ornith. Monogr. 60:44-64. 2006.

26. McLean, R. G., S. R. Ubico, D. E. Docherty, W. R. Hansen, L. Sileo, and T. S. McNamara. West Nile transmission and ecology in birds. Ann. N. Y. Acad. Sci. 951:54-57. 2001.

27. Nemeth, N. M., S. Beckett, E. Edwards, K. Klenk, and N. Komar. Avian mortality surveillance for West Nile virus in Colorado. Am. J. Trop. Med. Hyg. 76:431-437. 2007.

28. Nemeth, N., G. Kratz, E. Edward, J. Scherpelz, R. Bowen, and N. Komar. Evaluation of clinic-admitted raptors for West Nile virus surveillance. Emerg. Infect. Dis. 13:305-307. 2007.

29. New Jersey Department of Health and Senior Services. West Nile virus alert and FAQ sheets, with archived data. Available from: http://www. state.nj.us/health/cd/westnile/enceph.htm.

30. Patnaik, J., L. Juliusson, and R. Vogt. Environmental predictors of human West Nile virus infections, Colorado. Emerg. Infect. Dis. 13:1788-1790. 2007.

31. Pyle, P. Identification guide to North American birds, part 1: Columbidae through Ploceidae. Slate Creek Press, Bolinas, CA. 1997.

32. Reisen, W. K., C. M. Barker, R. Carney, H. D. Lothrop, S. S. Wheeler, J. L. Wilson, M. B. Madon, R. Takahashi, B. Carroll, S. Garcia, Y. Fang, M. Shafii, N. Kahl, S. Ashtari, V. Kramer, C. Glaser, and C. Jean. Role of corvids in epidemiology of West Nile virus in Southern California. J. Med. Entomol. 43:356-367. 2006.

33. Turell, M. J., M. Bunning, G. V. Ludwig, B. Ortman, J. Chang, T. Speaker, A. Spielman, R. McLean, N. Komar, R. Gates, T. McNamara, T. Creekmore, L. Farley, and C. Mitchell. DNA vaccine for West Nile virus infection in fish crows (Corvus ossifragus). Emerg. Infect. Dis. 9:1077-1081. 2003.

34. Wilcox, B. R., M. J. Yabsley, A. E. Ellis, D. E. Stallknecht, and S. E. J. Gibbs. West Nile virus antibody prevalence in American crows (Corvus brachyrhynchos) and fish crows (Corvus ossifragus) in Georgia, U.S.A. Avian Dis. 51:125-128. 2007.

35. Yaremych, S. A., R. E. Warner, P. C. Mankin, J. D. Brawn, A. Raim, and R. Novak. West Nile virus and high death rate in American Crows. Emerg. Infect. Dis. 10:709-711. 2004.

\section{ACKNOWLEDGMENTS}

We thank Robert Anderson, Priscilla Collins, Vivien Roegner, Kelsey Brooks, Ryan Neary, Bevin O'Grady, and Steve Piotrowski for technical assistance. Wayne Crans provided helpful suggestions on the manuscript. Marm Kilpatrick, Brad Biggerstaff, and Mark Delorey provided advice on data analysis. Funding was provided from the State Mosquito Control Commission of the New Jersey Department of Environmental Protection, the Centers for Disease Control and Prevention, the New Jersey Department of Health and Senior Services, and the Equine Science Center of the School for Environmental and Biological Sciences, Rutgers University. This is New Jersey Agricultural Experiment Station publication number D-08-08294-08-09. 